\title{
Synthesis of Calicoferol $\mathbf{E}$
}

\author{
Tej Vir Singh,* Raminder Kaur, Keshav Rai Agnihotri ${ }^{\dagger}$, and Manoj Bali \\ Department of Chemistry, Panjab University, Chandigarh - 160 014, India \\ ${ }^{\dagger}$ University Science Instrumentation Center, Panjab University, Chandigarh - 160 014, India \\ E-mail:tvs_chem@lycos.com
}

\begin{abstract}
Dedicated to Professor S.V. Kessar on the occasion of his $70^{\text {th }}$ birthday
(received 25 Apr 02; accepted 30 Jun 02; published on the web 08 Jul 02)
\end{abstract}

\begin{abstract}
A concise linear synthesis of 9,10 secosteroid Calicoferol E 6 has been completed. Key features of the process include: (i) the preparation of hitherto unknown $9 \alpha$-hydroxycholest-1, 4-diene-3one 5 from commercially available $5 \alpha$-cholestan- $3 \beta$-ol using conventional chemistry; (ii) the acid catalyzed rearrangement of 5 to give $\mathbf{6}$.
\end{abstract}

Keywords: 9,10-Secosterol, DDQ dehydrogenation, acid catalyzed aromatization, 3-keto-1,4diene

\section{Introduction}

Aromatic A-ring 9,10-secosteroids such as Calicoferol E and Astrogorgiadiol are naturally occurring biologically active compounds ${ }^{1}$. They have been isolated from a gorgonian of genus Calicogorgia and are toxic against brine shrimp larvae. These compounds are less studied vitamin $\mathrm{D}_{3}$ analogues ${ }^{2}$. Considerable efforts have already been directed towards the preparation of aromatic A ring 9,10-secosteroids either from 3-keto-4-ene and /or 3-keto-1,4-diene steroidal systems. The methods involve the use of techniques such as pyrolysis ${ }^{3}$, radical initiated processes $^{4}$ and microbial transformations ${ }^{5}$. These procedures however have severe limitations ${ }^{5,6}$ towards the manipulation and interconversion of substituents required in a natural product ${ }^{1}$. This problem was indeed solved in a recently reported ${ }^{6}$ convergent synthesis of Calicoferol E (6). The key step of this very lengthy synthesis is the radical coupling of des-AB-cholest-8methyledine-9-one (obtained from vitamin $\mathrm{D}_{3}$ via Grundmann's ketone) with 2-methyl-4$\operatorname{MEM}($ methoxyethoxymethyl)ether of benzyl iodide. Overall yield of the reported 14 step synthesis is $6.6 \%$. We report herein a short and convenient synthesis of Calicoferol E using $9 \alpha-$ hydroxycholesta-1,4-diene-3-one. It is essentially based on (i) deprotection of a 1,3-dioxalane derivative to ketone and dehydrogenation of $9 \alpha$-hydroxy-5 $\alpha$-cholestan-3-one by $\mathrm{DDQ}^{7}$ and (ii) 
the chemistry of acid catalyzed dienone-phenol rearrangement developed by Caine ${ }^{8}$.

\section{Results and Discussion}

The four step conversion of cholest-9(11)-ene-3-one $\mathbf{1}^{9}$ to the precursor $\mathbf{5}$ was carried out using conventional chemistry. The protection of keto function using ethyleneglycol in the presence of p-toluenesulphonic acid gave cyclic ketal in $87 \%$ yield. Treatment of $\mathbf{2}$ with $\mathrm{m}$ chloroperoxybenzoic acid in chloroform afforded $9 \alpha, 11 \alpha$-epoxide 3 in $61 \%$ yield. Reduction of 3 with lithium aluminumhydride in THF furnished $9 \alpha$-hydroxy-3-ethylenedioxy cholestane 4 $(79 \%)$.

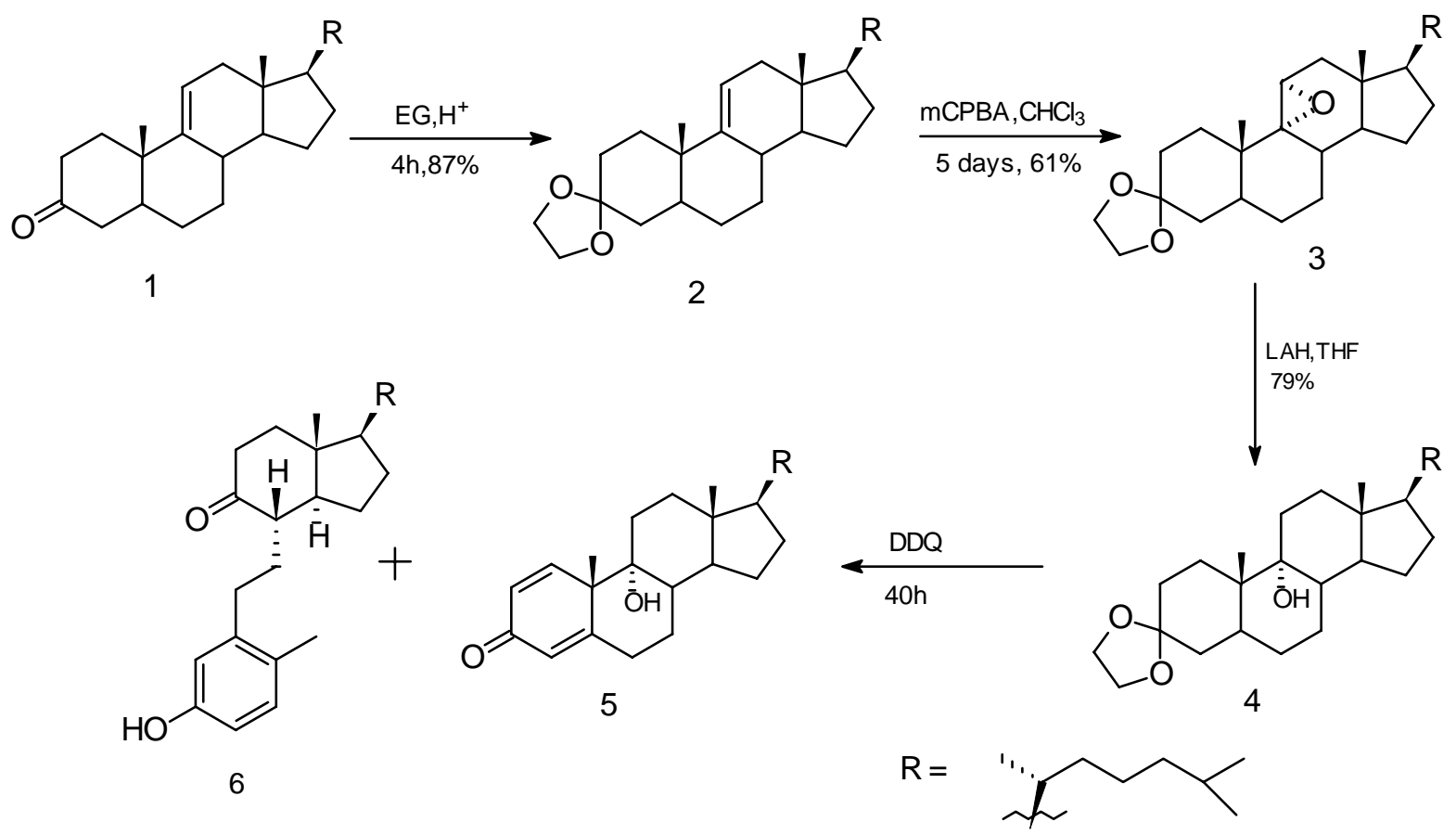

\section{Scheme 1}

The deketalization of $9 \alpha$-hydroxy-3-ethylenedioxy cholestane 4 was performed using DDQ 4 in catalytic amount. Further oxidation was continued by addition of more DDQ. 9 $\alpha$ hydroxycholestane-1,4-diene-3-one $5(8 \%)$ and Calicoferol E $6(2 \%)$ were isolated along with two minor products. The IR spectrum of 5 showed bands at $3440 \mathrm{~cm}^{-1}$ due to $-\mathrm{OH}$ and $1660 \mathrm{~cm}^{-1}$ due to cross conjugated dienone moiety. Its ${ }^{1} \mathrm{H}$ NMR showed the angular methyls at $\delta 0.73$ (18$\mathrm{Me})$ and $\delta 1.22(19-\mathrm{Me})$, doublet was seen at $\delta 6.02(\mathrm{~J}=2 \mathrm{~Hz})$ for olefinic proton at $\mathrm{C}-4$. The double doublet was observed at $\delta 6.18-6.22(\mathrm{~J}=10 \mathrm{~Hz}, 2 \mathrm{~Hz})$ due to olefinic proton at $\mathrm{C}-2$ and another double doublet was seen at $\delta 7.01-7.04(10 \mathrm{~Hz}, 2 \mathrm{~Hz})$ due to olefinic proton at $\mathrm{C}-1$. The mass spectrum showed the molecular ion at m/z 398, $\left(\mathrm{M}^{+}-\mathrm{H}_{2} \mathrm{O}\right)$ peak at m/z 380 and $\left[\mathrm{M}^{+}\right.$- 
$\left.\left(\mathrm{H}_{2} \mathrm{O}+\mathrm{CH}_{3}\right)\right]$ peak at $\mathrm{m} / \mathrm{z} 365$. Calicoferol-E 6 showed IR absorption bands at $3400 \mathrm{~cm}^{-1}(-\mathrm{OH})$ and $1712 \mathrm{~cm}^{-1}(\mathrm{C}=\mathrm{O})$. Its $\mathrm{UV}$ spectrum showed the absorption maximum at $\lambda 282 \mathrm{~nm}$ characteristic of $\mathrm{C}=\mathrm{O}\left(\mathrm{n} \pi^{*}\right)$. The ${ }^{1} \mathrm{H}$ NMR showed a singlet at $\delta 2.25(3 \mathrm{H}$, methyl group at aromatic ring), two doublets of triplet at $\delta 2.48$ and $2.66\left(2 \mathrm{H}, \mathrm{ArCH}_{2}-\mathrm{CH}_{2}-\right)$, a broad peak at $\delta 4.50(1 \mathrm{H}, \mathrm{ArOH})$, a double doublet at $\delta 6.54-6.58\left(\mathrm{~J}=7.97,2.75 \mathrm{~Hz}, 1 \mathrm{H}, \mathrm{C}_{2} \mathrm{H}\right)$, a doublet at 86.64-6.65 $\left(\mathrm{J}=2.6 \mathrm{~Hz}, 1 \mathrm{H}, \mathrm{C}_{4} \mathrm{H}\right)$ and a doublet at $\delta 6.96-6.99\left(\mathrm{~J}=8.5 \mathrm{~Hz}, 1 \mathrm{H}, \mathrm{C}_{1} \mathrm{H}\right)$. The Mass spectrum exhibited the molecular ion at $\mathrm{m} / \mathrm{z} 398$. The above data is in accord with literature ${ }^{1}$. Finally, the structure was confirmed by X-ray crystallography ${ }^{10}$ (Figure 1.)

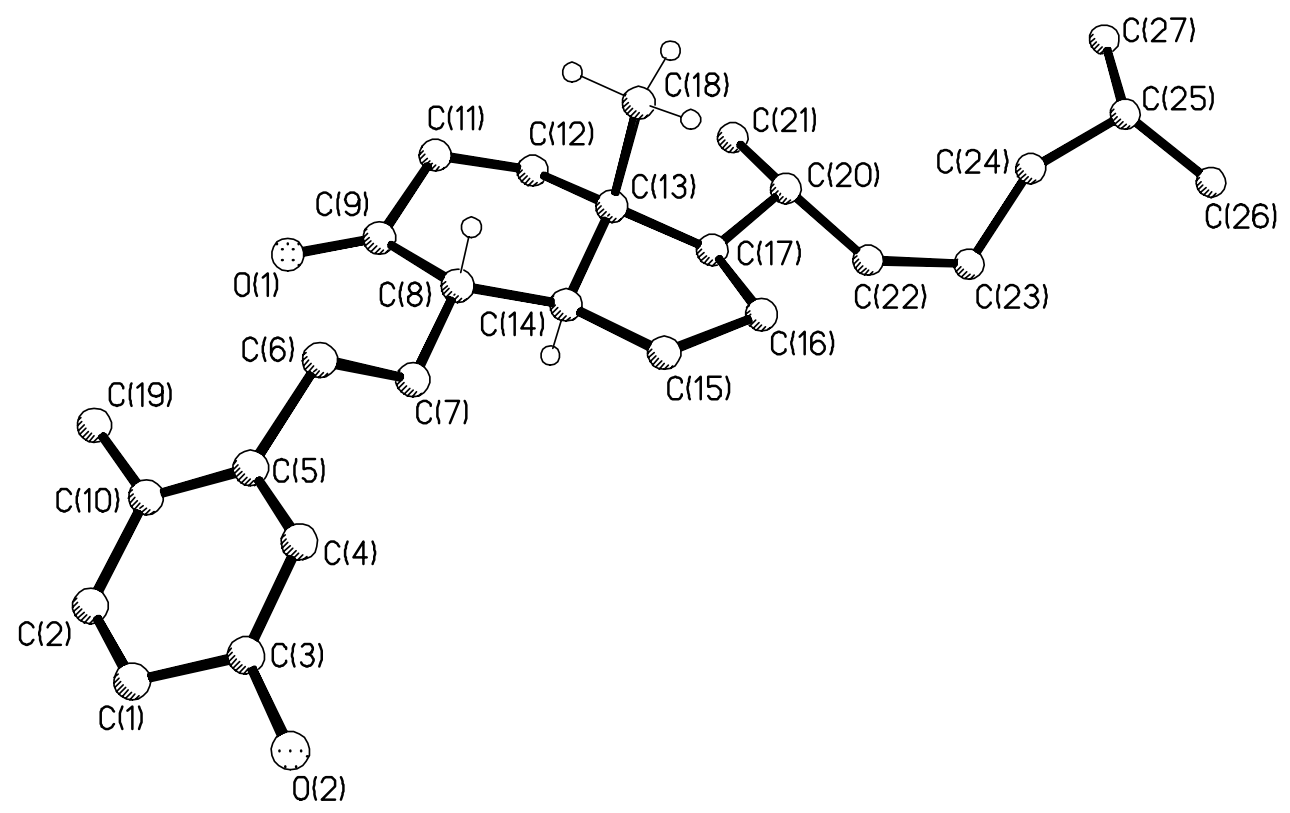

Figure 1. A perspective view of Calicoferol E (6) with atom numbering scheme. Hydrogens of $\mathrm{C} 8, \mathrm{C} 14$ and $\mathrm{C} 18$ are shown to highlight the stereochemistry at these centers. Other hydrogens are omitted for clarity.

In another experiment the reaction of $9 \alpha$-hydroxy-3-ethylenedioxy cholestane 4 with DDQ produced $9 \alpha$-hydroxycholest-1-ene-3-one 7 as the major product (49\%). $9 \alpha$-Hydroxycholest-1ene-3-one 7 was a white solid (m.p. $120-121^{\circ} \mathrm{C}$ ). Its UV spectrum showed an absorption maximum at $\lambda 226 \mathrm{~nm}$. The ${ }^{1} \mathrm{H}$ NMR displayed a singlet at $\delta 0.71(3 \mathrm{H}, 18-\mathrm{Me})$, a singlet at $\delta$ $1.10(3 \mathrm{H}, 19-\mathrm{Me}), \mathrm{C}-1, \mathrm{C}-2$ protons appeared at $\delta 5.93,7.21\left(\mathrm{~J}_{\mathrm{HH}}=10 \mathrm{~Hz}\right)$. The ${ }^{13} \mathrm{C}$ NMR showed carbonyl carbon at $\delta 199.9(\mathrm{C}-3)$, the two olefinic carbons at $\delta 157.6(\mathrm{C}-2)$ and $128.9(\mathrm{C}-1)$ and carbon bearing $-\mathrm{OH}$ group at $\delta 74.9$ (C-9). The MS showed the molecular ion at $\mathrm{m} / \mathrm{z} 400$, the $\left[\left(\mathrm{M}^{+}-\mathrm{H}_{2} \mathrm{O}+\mathrm{CH}_{3}\right)\right]$ at $\mathrm{m} / \mathrm{z} 367$. The HRMS gave the molecular ion exact mass as 400.3336 (calculated 400.3341). 

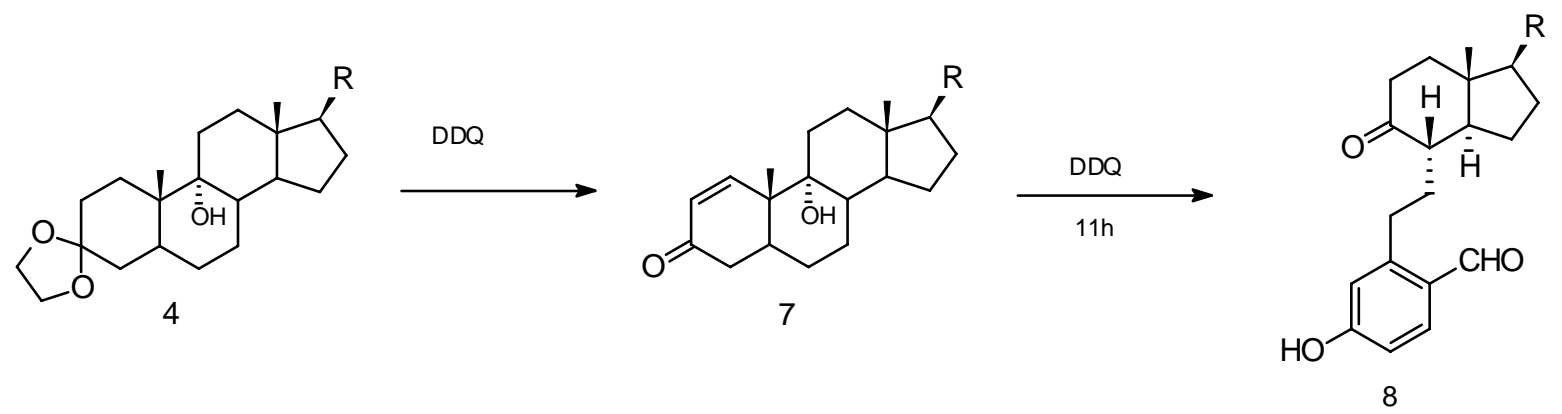

Scheme 2

$9 \alpha$-Hydroxycholest-1-ene-3-one 7 was further subjected to DDQ treatment and a single product 8 was obtained in $86 \%$ yield. Its IR spectrum showed bands at $3320 \mathrm{~cm}^{-1}(-\mathrm{OH}), 2730$ and $1695 \mathrm{~cm}^{-1}(-\mathrm{CHO})$ and $1712 \mathrm{~cm}^{-1}(\mathrm{C}=\mathrm{O})$. The ${ }^{1} \mathrm{H}$ NMR displayed a doublet of triplet at $\delta 2.92-$ $2.88\left(\mathrm{Ar}-\mathrm{CH}_{2}-\mathrm{CH}_{2}-\right)$, a doublet of triplet at $\delta 3.05-3.09\left(\mathrm{Ar}-\mathrm{CH}_{2}-\mathrm{CH}_{2}-\right)$, a double doublet at $\delta$ $6.72-6.84(2 \mathrm{H}$, aromatic), a singlet at $\delta 7.22-7.75(1 \mathrm{H}$, aromatic) and a singlet at $\delta 10.12(-\mathrm{CHO})$. The ${ }^{13} \mathrm{C}$ NMR showed the peaks at $\delta 214.6(-\mathrm{CHO}), 191.1(\mathrm{C}=\mathrm{O})$ and 161.2, 148.8, 134.9, 127.2, $117.5,113.8,96.2$. The mass spectrum showed the molecular ion at $\mathrm{m} / \mathrm{z} 412$. Its exact mass from HRMS was 412.2972 (calculated 412.2977). On the basis of forgoing data the structure 8 was assigned to this product. The mechanism for the formation of $\mathbf{8}$ as well as $\mathbf{6}$ may be visualized as depicted below Scheme 3. The dehydrogenation of 7 occurs with DDQ to form $\mathbf{5}$. Its intermediacy has already been established during the formation of 6 from 4 (Scheme 1).

Calicoferol E (6) undergoes benzylic oxidation at C-19 with $\mathrm{DDQ}^{11}$ to give phenolic aldehyde 8 via the alcohol 9.

In summary, we have presented the first linear synthesis of calicoferol E (6), with the use of rearrangement of $9 \alpha$-hydroxycholest-1,4-diene-3-one to calicoferol $\mathrm{E}$. We believe that it is possibly the first biomimetic construction of this molecule. The low yield of calicoferol E 6 may be attributed to the fact that the treatment with DDQ is responsible for various transformations such as deketalisation, dehydrogenation, oxidation of tertiary alcohol, aromatisation followed by $\mathrm{C}-\mathrm{C}$ bond cleavage. Besides this, further oxidation of the natural product is detrimental. The attempts to control the over oxidation product(s) are in progress. 


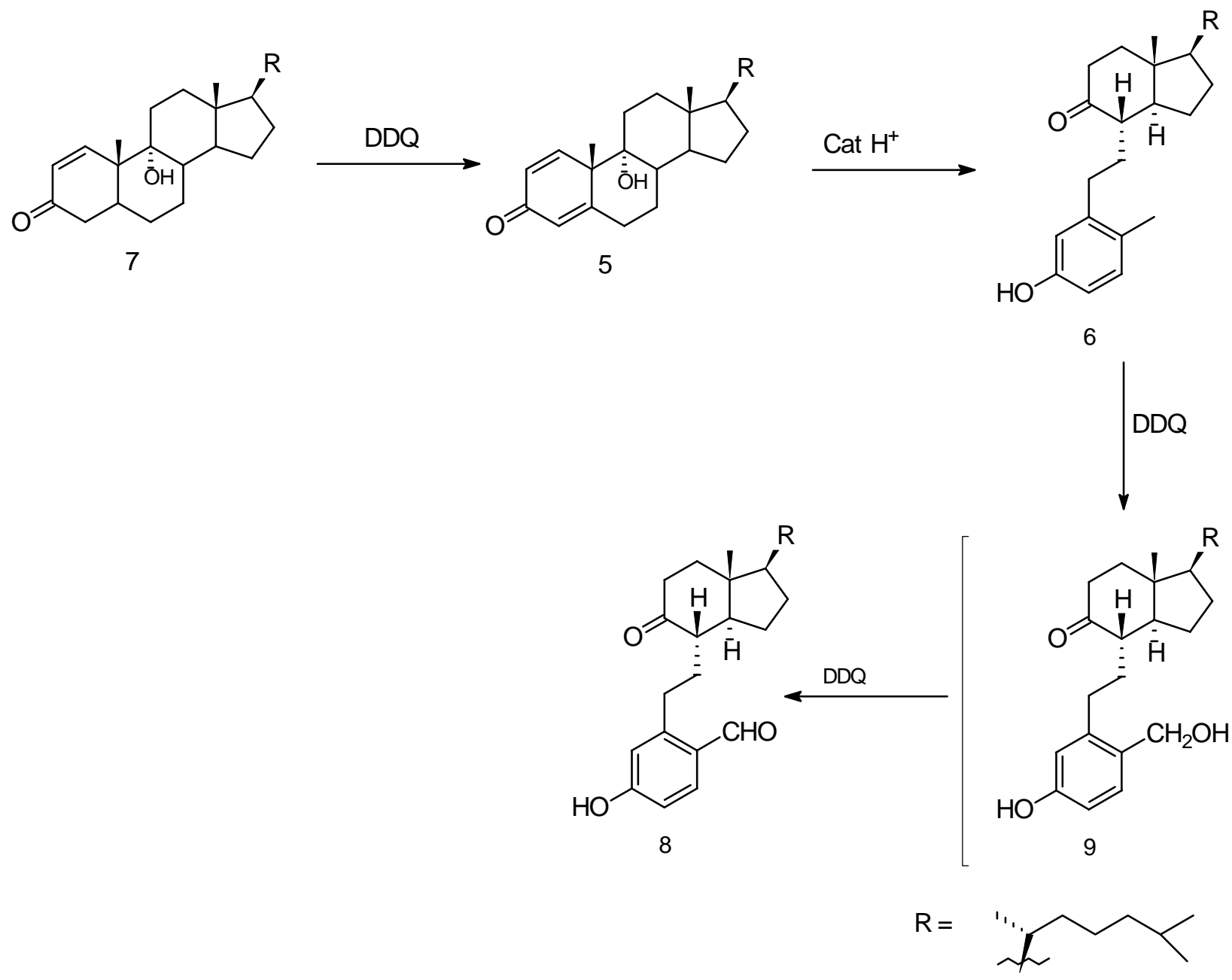

\section{Scheme 3}

\section{Experimental Section}

General Procedures. Melting points were determined in Thomas Hoover apparatus and are uncorrected. IR spectra were recorded with Perkin-Elmer model 1430 spectrophotometer. ${ }^{1} \mathrm{H}$ NMR spectra were recorded on a Varian EM-390 (90MHz) and Brücker ACF300 (300MHz) using TMS as internal standard. ${ }^{13} \mathrm{C}$ NMR spectra were also recorded on ACF300 instrument. Mass spectra were recorded on VG analytical 70-250S machine and the relative intensities of all peaks are given in parentheses, Cholestanol and DDQ were purchased from Fluka (Switzerland) and used as such.

Cholest-9(11)-ene-3-one (1). Cholest-9(11)-ene-3-one 1 can be readily obtained in over all yield of $52 \%$ from $5 \alpha$-Cholestane-3 $\beta$-ol, followed by Jones oxidation, ${ }^{9,2 \mathrm{c}}$, mp. $109-110^{\circ} \mathrm{C}$ (methanolether) $\left(1 \mathrm{it}^{2 \mathrm{c}} 109-110^{\circ} \mathrm{C}\right)$. 
3-Ethylenedioxycholest-9(11)-ene (2). A solution of cholest-9(11)-en-3-one 1 (8.34g, $21.71 \mathrm{mmol})$, ethylene glycol $(1.33 \mathrm{~mL}, 23.88 \mathrm{mmol})$ and $p$-toluenesulphonic $(10 \mathrm{~mole} \%)$ acid in benzene $(80 \mathrm{~mL})$ was heated under reflux for $4 \mathrm{~h}$ using a Dean and Stark water separator . Benzene was removed and the residue was dissolved in ether $(250 \mathrm{~mL})$. The ether mixture was washed with $5 \%$ aq. $\mathrm{NaOH}(3 \times 100 \mathrm{~mL})$, water $(4 \times 150 \mathrm{~mL})$ and dried. Removal of ether yielded a light yellow coloured solid $(8.47 \mathrm{~g})$. Purification by flash chromatography afforded a white solid, mp. 99-101 ${ }^{\circ} \mathrm{C}(8.08 \mathrm{~g}, 87 \%)$. IR $\left(\mathrm{CCl}_{4}\right): 1560 \mathrm{~cm}^{-1}(\mathrm{C}=\mathrm{C}) ;{ }^{1} \mathrm{H}$ NMR $\left(90 \mathrm{MHz}, \mathrm{CCl}_{4}\right) \delta 5.2(\mathrm{~d}, 1 \mathrm{H}$, $11-\mathrm{H}$ ); 3.8 (s, 4H, -O- $\mathrm{CH}_{2}-\mathrm{CH}_{2}-\mathrm{O}-$ ); 2.1-0.6 (m, 43H, steroidal envelope); 0.99 (s, 3H, 19-Me), 0.6 (s, 3H, 18-Me), HRMS calculated for $\mathrm{C}_{29} \mathrm{H}_{48} \mathrm{O}_{2} 428.3654$ found 428.3664 .

9 $\alpha, 11 \alpha$-Epoxy-3-ethylenedioxycholestane (3). A solution of 3-ethylenedioxy cholest-9(11)ene $2(7.89 \mathrm{~g}, 18.44 \mathrm{mmol})$ and $m$-chloroperoxybenzoic acid $(55 \%, 11.84 \mathrm{~g})$ in chloroform $(125 \mathrm{~mL})$ was stirred at room temperature for 5 days. The progress and completion of reaction was monitored by TLC. The chloroform mixture was treated with sodium meta bisulphite $(2 \times 100 \mathrm{~mL})$. The aqueous layer was extracted with chloroform $(2 \times 100 \mathrm{~mL})$. The combined chloroform extract was washed with water $(4 \times 150 \mathrm{~mL})$, aq. $\mathrm{Na}_{2} \mathrm{CO}_{3}(2 \times 150 \mathrm{~mL})$ and brine $(2 \times 150 \mathrm{~mL})$ and dried. Chloroform was distilled off under reduced pressure to give a white solid (7.83g). It was purified by flash chromatography (hexane, ethyl acetate, 97.5:2.5) to obtain a white solid. mp. $144-145^{\circ} \mathrm{C}(5 \mathrm{~g} .61 \%) .{ }^{1} \mathrm{H} \mathrm{NMR}\left(90 \mathrm{MHz}, \mathrm{CDCl}_{3}\right) \delta 3.79$ (s, 4H, - $\left.\mathrm{OCH}_{2}-\mathrm{CH}_{2} \mathrm{O}-\right)$, 2.94 (d, IH, $J=6 \mathrm{~Hz},-\mathrm{CHOC}), 0.90(\mathrm{~s}, 3 \mathrm{H}, 19-\mathrm{Me}), 0.60(\mathrm{~s}, 3 \mathrm{H}, 18-\mathrm{Me}) ; \mathrm{LRMS} \mathrm{m} / \mathrm{z}$ (relative intensity) 444(59), 292(21), 289(19), 231(13), 168(13), 145(11), 133(10), 125(47), 115(40), 107(19), 99(100). HRMS calculated for $\mathrm{C}_{29} \mathrm{H}_{48} \mathrm{O}_{3} 444.3603$, found 444.3614 .

9 $\alpha$-Hydroxy-3-ethylenedioxycholestane (4). To lithium aluminum hydride $(2.56 \mathrm{~g}, 67.62 \mathrm{mmol})$ was added a solution of $9 \alpha, 11 \alpha$-epoxy-cholestan-3-ethylenedioxide $\mathbf{3}(5.0 \mathrm{~g}, 11.27 \mathrm{mmol})$ in dry THF $(115 \mathrm{~mL})$ under nitrogen atmosphere. The reaction mixture was heated under reflux for $18 \mathrm{~h}$, under nitrogen atmosphere. After cooling to room temperature, aq. $\mathrm{NaOH}$ solution $(1 \mathrm{~N}, 12.5 \mathrm{~mL})$ was added slowly, followed by sodium sulphate and the mixture was filtered using a sintered funnel. The filtrate was evaporated to yield a white solid, m.p.130-132 $\mathrm{C}(5.52 \mathrm{~g})$. Recrystallization from ethanol afforded white needles, mp. 147-148 ${ }^{\circ} \mathrm{C}(4 \mathrm{~g}, 79 \%) .{ }^{1} \mathrm{H}$ NMR $\left(60 \mathrm{MHz}, \mathrm{CCl}_{4}\right), \delta 3.89\left(\mathrm{~s}, 4 \mathrm{H},-\mathrm{O}-\mathrm{CH}_{2}-\mathrm{CH}_{2}-\mathrm{O}-\right)$, 3.68(brs, IH, -OH, exchangeable), 0.93(s, 3H, $\left.\mathrm{CH}_{3}\right), 0.6\left(\mathrm{~s}, 3 \mathrm{H},-\mathrm{CH}_{3}\right)$. MS m/z (relative intensity) 446( $\left.\mathrm{M}^{+}, 24.5\right), 428\left(\mathrm{M}^{+}-\mathrm{H}_{2} \mathrm{O}, 16\right), 155(14)$, 125(61), 105(12), 99(100). HRMS calculated for $\mathrm{C}_{29} \mathrm{H}_{50} \mathrm{O}_{3} 446.3759$, found 446.3756 .

Treatment of $9 \alpha$-hydroxy-3-ethylenedioxy cholestane (4) with DDQ. A solution $9 \alpha$-hydroxy3-ethylenedioxy cholestane $4(0.91 \mathrm{~g}, 2.04 \mathrm{mmol})$, DDQ $(0.092 \mathrm{~g}, 0.40 \mathrm{mmol})$ and dioxane $(40 \mathrm{~mL})$ was heated under reflux for $16 \mathrm{~h}$. DDQ $(1.38 \mathrm{~g}, 6.12 \mathrm{mmol})$ was again added in three installments at $8 \mathrm{~h}$ interval, and the reaction mixture was heated under reflux for $40 \mathrm{~h}$. Filtration through sintered glass funnel afforded a reddish brown filtrate which was evaporated in vacuum to yield a dark oily residue $(0.995 \mathrm{~g})$. This was filtered through a small silica gel (40-60 $\mu$ ) pad using hexane/ethyl acetate (80:20) and the filtrate was evaporated under reduced pressure to yield a faint yellow viscous material. This was purified by flash chromatography (hexane, ethyl acetate; 
92.5:7.5) to provide four compounds, out of which only two could be identified.

9a-Hydroxycholestan-1,4-dien-3-one (5). $67.8 \mathrm{mg}$ (viscous oil). IR $\left(\mathrm{CH}_{2} \mathrm{Cl}_{2}\right) ; 3440,1660 \mathrm{~cm}^{-1}$; ${ }^{1} \mathrm{H}$ NMR $\left(300 \mathrm{MHz} \mathrm{CDCl}_{3}\right) \delta$ 7.04-7.01 (dd, $\left.J=10 \mathrm{~Hz}, 2 \mathrm{~Hz}, 1 \mathrm{H}, 1-\mathrm{H}\right) ; 6.22-6.18(\mathrm{dd}, J=10 \mathrm{~Hz}$, $2 \mathrm{~Hz}, 1 \mathrm{H}, 2-\mathrm{H}), 6.02$ (d, J=2 Hz, 1H, 4-H), 1.22 (s, 3H, 19- $\left.\mathrm{CH}_{3}\right), 0.73\left(\mathrm{~s}, 3 \mathrm{H}, 18-\mathrm{CH}_{3}\right), 2.5-0.85$ (steroidal protons) ${ }^{13} \mathrm{C}$ NMR $\left(75 \mathrm{MHz}, \mathrm{CDCl}_{3}\right) \delta 186.5(\mathrm{C}-3), 169.7(\mathrm{C}-5), 156.2(\mathrm{C}-1), 127.4(\mathrm{C}-2)$, 123.7(C-4), 64.2(C-9); LRMS m/z (relative intensity ) 398( $\left.\mathrm{M}^{+}, 29\right), 380(64), 365(16), 267(35)$, 259(17), 247(72), 173(52), 159(51), 147(40), 122(100); HRMS calculated for $\mathrm{C}_{27} \mathrm{H}_{42} \mathrm{O}_{2}$ 398.3184, found 398.3197.

Calicoferol-E (6). $15.7 \mathrm{mg}$ (white solid) $\mathrm{mp} .94-95^{\circ} \mathrm{C}\left(\mathrm{Lit}^{6} \mathrm{mp} \cdot 94-95^{\circ} \mathrm{C}\right)$; $[\alpha]_{\mathrm{D}}{ }^{23}+23.6$; UV $(\mathrm{MeOH}) \lambda_{\max }(\log \varepsilon) 218$ (3.95), 282 (3.39) nm; IR(neat) 3400, 1742, 1712, $1462 \mathrm{~cm}^{-1} ;{ }^{1} \mathrm{H}$ NMR $\left(300 \mathrm{MHz} \mathrm{CDCl}_{3}\right) \delta 6.99-6.96(\mathrm{~d}, J=8.5 \mathrm{~Hz}, 1 \mathrm{H}, 1-\mathrm{H}), 6.65-6.64(\mathrm{~d}, J=2.6 \mathrm{~Hz}, 1 \mathrm{H}, 4-\mathrm{H}), 6.58-$ 6.54(dd, J=7.97 Hz, 2.75Hz, 1H, 2-H), 4.50(brs 1H,-OH), 2.66 (m, 1H, 6-H), 2.48(m, 1H, 6-H), 2.25(s, 3H, $\left.-\mathrm{CH}_{3}\right) .{ }^{13} \mathrm{C}$ NMR $\left(75 \mathrm{MHz}, \mathrm{CDCl}_{3}\right) 213.6(\mathrm{C}-5), 131.1$ (C-1), $127.9(\mathrm{C}-10), 115.8(\mathrm{C}-$ 4), 112.6 (C-2), 55.33(C-14), 55.12 (C-17), 50.5 (C-8), 42.9 (C-13), 35.9 (C-24), 38.4 (C-11), 38.5(C-12), 35.9 (C-22), 35.7 (C-20), 31.1 (C-6), 29.1 (C-16), 28.1(C-25), 27.7(C-7), 25.2(C-15), 23.9(C-23), 22.9(C-26), 22.6(C-27), 18.6(C-21), 18.4(C-19), 11.6(C-18), LRMS m/z relative intensity $398\left(\mathrm{M}^{+}, 24\right) 264$ (29), 294 (9), 193(39), 180(6), 157(70), 134(100), 121(48), 109 (9); HRMS calculated for $\mathrm{C}_{27} \mathrm{H}_{42} \mathrm{O}_{2} 398.3185$ found 398. 3178 .

X-ray Crystallography. Needle shaped single crystals of compound $\mathbf{6}$ were grown from benzene-dichloromethane $(2: 1 ; \mathrm{v} / \mathrm{v})$ and a crystal with dimension $0.27 \times 0.15 \times 0.12 \mathrm{~mm}$ was mounted along its largest dimension and used for data collection. The crystals, in general, were weakly diffracting and the peak-width was high, deterring a good intensity data collection. Nevertheless, the molecular features and thus the identity of $\mathbf{6}$ is very clear from the diffraction experiment. The structure was solved by Direct Methods using SHELX-97 ${ }^{10}$ package and also refined using the same one. During the refinement, it is observed that the aliphatic side chain was severely disordered with high thermal parameter values and hence were only refined isotropically. Other non-hydrogen atoms were refined anisotropically. The hydrogen atoms, except those of side chain, were included in the ideal positions with fixed isotropic $U$ values and were riding. Crystal data for 6: $\mathrm{C}_{27} \mathrm{H}_{42} \mathrm{O}_{2}, \mathrm{M}_{\mathrm{r}}=398.61$, Orthorhombic, $\mathrm{P} 2{ }_{1} 2_{1} 2$, $\mathrm{a}=8.510(2)$, $b=14.126(2), \quad c=20.938(4) \AA, \quad V=2516.9(9) \AA^{3}, \quad Z=4, \quad M o K \alpha, \quad \lambda=0.71073 \AA, T=293(1) K$, $\mathrm{GOOF}=0.965, \mathrm{R}=0.1635, \mathrm{wR}=0.3360$ for 1179 reflections $[\mathrm{F}>4 \sigma(\mathrm{F})]$.

Treatment of $9 \alpha$-hydroxy-3-ethylenedioxycholestane (4) with DDQ. To a solution $9 \alpha$ hydroxy-3-ethylenedioxy cholestane $4(3.89 \mathrm{~g}, 8.73 \mathrm{mmol})$ in dioxane $(175 \mathrm{ml})$ was added DDQ $(0.407 \mathrm{~g}, 8.73 \mathrm{mmol})$ and the reaction mixture was heated under reflux for $16 \mathrm{~h}$ under nitrogen atmosphere. DDQ $(6.10 \mathrm{~g}, 26.9 \mathrm{mmol})$ was added in three installments at intervals of $11-12 \mathrm{~h}$. The reaction mixture was refluxed under nitrogen atmosphere, the progress of reaction being monitored by TLC and HPLC. The reaction mixture was filtered to remove phenols. Dioxane was evaporated from filtrate under vacuo. The residue was purified by flash chromatography 
(hexane: ethylacetate; 9:1) to yield three components including $9 \alpha$-hydroxycholesta-1-en-3-one 7. 9a-Hydroxycholestan-1-en-3-one (7). $1.72 \mathrm{~g}, \mathrm{mp} .120-121^{\circ} \mathrm{C}$, UV (ethanol) $\lambda_{\max }(\log \varepsilon$ ) $226 \mathrm{~nm} ; \mathrm{IR}\left(\mathrm{CHCl}_{3}\right) 3400,1665 \mathrm{~cm}^{-1} ;{ }^{1} \mathrm{H} \mathrm{NMR}\left(300 \mathrm{MHz} \mathrm{CDCl}_{3}\right) \delta 7.22-7.19$ (dd, $J=10 \mathrm{~Hz}, 1 \mathrm{H}$, olefinicH), 5.95-5.91(d, $1 \mathrm{H}, J=10 \mathrm{~Hz}$, olefinic $\mathrm{H}), 1.10\left(\mathrm{~s}, 3 \mathrm{H}, 19-\mathrm{CH}_{3}\right), 0.71\left(\mathrm{~s}, 3 \mathrm{H}, 18-\mathrm{CH}_{3}\right)$, 2.63-0.85 (steroidal protons) ${ }^{13} \mathrm{C}$ NMR $\left(75 \mathrm{MHz}, \mathrm{CDCl}_{3}\right) \delta 199.9(\mathrm{C}=\mathrm{O}), 157.6(\mathrm{C}-2), 128.9(\mathrm{C}-1)$, 74.9(C-9); LRMS m/z (relative intensity ) 400( $\left.\mathrm{M}^{+}, 7\right), 382(25), 367(12), 269(10), 243(13)$, 134(100), 122(19); HRMS calculated for $\mathrm{C}_{27} \mathrm{H}_{44} \mathrm{O}_{2} 400.3341$, found 400.3336 .

Treatment of $9 \alpha$-hydroxycholest-1-en-3-one (7) with DDQ. A solution of $9 \alpha$-hydroxycholest1-en-3-one 7 (0.05 g, $0.12 \mathrm{mmol})$, DDQ $(85 \mathrm{mg}, 0.37 \mathrm{mmol})$ and dioxane $(5 \mathrm{~mL})$ was heated under reflux for $11 \mathrm{~h}$. The reaction mixture was filtered to remove phenols. The dark red colored filtrate was evaporated and the residue was purified by flash chromatography (hexane: ethylacetate; 9:10) to yield aldehyde $8(12 \mathrm{mg}, 86 \%)$. IR $\left(\mathrm{CHCl}_{3}\right) 3320,2730,1712,1695,1580,1470 \mathrm{~cm}^{-1} ;{ }^{1} \mathrm{H} \mathrm{NMR}$ $\left(300 \mathrm{MHz} \mathrm{CDCl}_{3}\right) \delta 10.12(\mathrm{~s}, 1 \mathrm{H},-\mathrm{CHO}), 7.75-7.72(\mathrm{~d}, 1 \mathrm{H}, 1-\mathrm{H}), 7.10(\mathrm{~s}, 1 \mathrm{H},-\mathrm{OH}$, exchangeable), 6.84-6.72(dd, 2H,2-H and 4-H), 3.09-3.05(ddd, 2H, benzylic $\left.-\mathrm{CH}_{2}-\right), 2.92-2.88\left(\mathrm{ddd}, 1 \mathrm{H}, \mathrm{Ar}-\mathrm{CH}_{2}\right)$, 2.53-0.70(m, steroidal envelope). ${ }^{13} \mathrm{C}$ NMR (75 MHz, $\left.\mathrm{CDCl}_{3}\right) \delta 214.6(\mathrm{C}=\mathrm{O}), 191.1(\mathrm{C}=\mathrm{O}) 161.2$, 148.8, 134.9, 127.2, 117.5, 113.9, 96.2; LRMS m/z (relative intensity) 412(2), 394(47), 263(100), 249(9), 193(35), 151(66), 136(23), 134(22), 133(22), 122(8), 121(16), 107(32), 93(31); HRMS calculated for $\mathrm{C}_{27} \mathrm{H}_{40} \mathrm{O}_{3} 412.2977$ found 412.2972.

\section{Acknowledgements}

The authors express their gratitude to the CSIR New Delhi 01(1461)/97/EMRII for financial assistance. One of us (RK) is also thankful to UGC, New Delhi for Junior Research Fellowship, through CAS of this department. Authors are also thankful to P. Venugopalan, Chemistry Department, P.U. Chandigarh for the X-ray crystal studies of the natural product.

\section{References and Notes}

1. (a) Fusetani, N.; Nagata, H.; Hirota, H; Tsyuki, T. Tetrahedron Lett. 1989, 50, 7079. (b) Seo, Y.; Shin, J. J. Natural Products 1995, 58, 1291.

2. (a) Zhy, G. D.; Okamura, W. H.; Chem. Rev. 1995, 95, 1877. and references cited .(b) Taber, D. F.; Malcom, S. C. J. Org. Chem. 2001, 66, 944. (c) Lythgoe, B.; Roberts, D. A. J. Chem. Soc., Perkin Trans I 1980, 892.

3. Magerlein, B. J.; Hogg, J. A. Tetrahedron Lett. 1958, 2, 80.

4. (a) Tasuda, K.; Ohki, E.; Nozoe, S.; Ikekawa, N. J. Org. Chem. 1961, 26, 2614. (b) Morisaki, M.; Izawa, H.; Tasuda K. Chem. Pharm. Bull. 1966, 14, 866. (c) Künzer, H.; Sauer, G.; Wiechart, R. Tetrahedron Lett. 1991, 32, 7247. (d) Ananthanarayan, T. P.; 
Gallagher, T.; Megnus, P. J. Chem. Soc., Chem. Commun 1982, 709.

5. (a) Matho, S. B.; Banerjee, S.; Podder, S.; Majumdar, I. Phytochemistry 1989, 28, 7. (b) Dodson, R. M.; Muir, R. D. J. Am. Chem. Soc. 1958, 80, 5004. (c) Nagasawa, M.; Bae, M.; Tamura, G.; Arima, K. Agr. Biol. Chem. 1963, 33, 1644; Chem. Abstr. 1970, 72, 399 60z.

6. Sala, G. D.; Izzo, I.; De Riccardis, F.; Sodano, G. Tetrahedron Lett. 1998, 39, 4741.

7. (a) Walker, D.; Hibert, J.D. Chem. Rev. 1967, 67, 153. (b) House HO, Modern Synthetic Reactions $2^{\text {nd }}$ Edn; Benjamin Cummings, 1972; p 43.

8. Caine, D.; Kotian P. L. ; McGuiness M. D. J. Org. Chem. 1961, 56, 6307.

9. Breslow, R.; Corcoran, R. J.; Snider, B. B.; Doll, R. J.; Khanna, P. L.; Kaleya, R. J. Am. Chem. Soc. 1977, 99, 905.

10. SHELX-97 G.M.Sheldrick, Program for the solution and refinement of crystal structures, University of Göttingen, Göttingen, Germany, 1997.

11. (a) Becker, H. D. J. Org. Chem. 1965, 30, 982. (b) Panetta, C. A.; Fang, Z.; Mattern, D.L. J. Org. Chem. 1995, 60, 7953. 